\title{
Association of Insulin Resistance, $\beta$-Cell Function Impairment and Calcium, Magnesium, and Fetuin-A Concentrations in Women with Type 2 Diabetes Mellitus
}

\author{
Shatha Rouf Moustafa \\ Academic Faculty at College of Pharmacy, Hawler Medical University, Erbil, Iraq
}

\author{
SUMMARY
}

Insulin resistance and $\beta$-cell function impairment play a role in the pathogenesis of type 2 diabetes (T2DM). Insulin signaling is inhibited by fetuin-A, an abundant plasma protein. Fetuin-A is also a candidate marker of the T2DM risk. This case-control study aimed to determine whether fetuin-A serum level is related to insulin resistance, $\beta$-cell function impairment, and total and ionized Ca and Mg serum levels in Erbil patients with T2DM.

A total of 60 patients with T2DM were recruited, and 30 healthy persons were included in the control group. Fetuin-A and insulin concentrations were measured through ELISA. Other biochemical parameters were determined spectrophotometrically. Insulin resistance (HOMA2IR), insulin sensitivity (HOMA2\%S), and $\beta$-cell function were examined by using a homeostatic model assessment 2 (HOMA2).

Fasting serum insulin, fetuin-A serum levels, and HOMA2IR were significantly increased. HOMA2\%S of the patients with diabetes was significantly lower than that of the control group. The total serum and ionized $\mathrm{Ca}$ and $\mathrm{Mg}$ contents and the $\mathrm{Ca} / \mathrm{Mg}$ ratio were reduced in the patients.

Therefore, fetuin-A is related to T2DM pathogenesis and is strongly associated with insulin resistance and glycemic control in T2DM patients. Future large-scale studies are necessary to validate fetuin-A as an indicator of IR in T2DM patients.

Key words: Ca, fetuin-A, type 2 diabetes mellitus, insulin resistance, $\mathrm{Mg}$ 


\section{INTRODUCTION}

Type 2 diabetes mellitus (T2DM) is a major health problem worldwide. Six people die from T2DM every minute; as a consequence, T2DM is a serious cause of mortality worldwide (1). In patients with T2DM, tyrosine kinase activity is impaired at the insulin receptor and thus produces very high calcium (Ca) levels in cells. These two effects are necessary to reduce insulin action and promote insulin resistance (IR) in patients with T2DM (2). In T2DM pathogenesis, insulin production from $\beta$-pancreatic cells should be reduced, IR should be increased, and insulin sensitivity should be decreased (3). Multiple factors are involved in T2DM pathogenesis. One of these factors is alpha2Heremans-Schmid glycoprotein, which is also known as fetuin-A (4).

Fetuin-A is an abundant plasma protein in humans. Fetuin-A abolishes the activity of insulin receptor tyrosine kinase in vitro and in rodents (5). Fetuin-A also increases the risk of diabetes in humans with increased blood glucose levels (6). This protein protects blood vessels from calcification by increasing the solubility of calcium and phosphorous in the serum (7).

Similar to fetuin-A, Ca is necessary to promote insulin receptor phosphorylation and proper signal transduction. Variations in Ca uptake elicit side effects on insulin production, which is a calcium-dependent process. Ca neutralizes glucose tolerance and insulin production in vitamin D-depleted rats (8). When insulin receptor phosphorylation is disrupted, insulin signal transduction is abolished and glucose transporter- 4 activity is decreased. Therefore, Ca likely plays significant roles in insulin activity and secretion.

$\mathrm{Mg}$ activates all enzymatic reactions that require ATP or kinase (9). Mg also participates in carbohydrate metabolism. It stimulates secretion and insulin activity (10). IR and Mg reduction stimulate the cycle of losing IR and decreasing intracellular $\mathrm{Mg}^{2+}$, which limit $\mathrm{Mg}$ functioning in cell processes (11).

The link between DM and $\mathrm{Mg}$ depletion has been elucidated. Insulin stimulates the movement of $\mathrm{Mg}$ from extracellular to intracellular compartments. $\mathrm{Ca}$ and $\mathrm{Mg}$ intake is inversely associated with the T2DM risk in white populations. A diet with high-Mg food, particularly whole grains, is related to a decreased risk of T2DM in black American women (12). Serum Mg level decreases and RBC Mg concentration significantly increases $(p<0.05)$ because of insulin activity in fasting healthy adults without a history of diabetes (13). IR in relation to T2DM is correlated with decreased intracellular $\mathrm{Mg}$. IR in skeletal muscles can be decreased by $\mathrm{Mg}$ intake.

This study aimed to investigate whether plasma fetuin-A concentration predicts the incidence of T2DM. This study also aimed to examine the factors affecting the possible changes in fetuin-A levels in patients with T2DM. The examined factors included insulin sensitivity (HOMA\%S), IR (HOMA2IR), and $\beta$-cell functions, which were determined by using a special model named homeostatic model assessment. Total protein serum level, albumin content, globulin content, albumin-to-globulin ratio, and total and ionized $\mathrm{Ca}$ and $\mathrm{Mg}$ concentrations in Erbilian patients with T2DM were estimated and compared with those in the control group. The correlation between the studied parameters was also determined.

\section{SUBJECTS AND METHODS}

This study aimed to predict the relationship between fetuin-A level as independent markers of IR, insulin sensitivity, $\beta$-cell function, serum total protein level, albumin content, globulin content, albumin-toglobulin ratio, and total and ionized $\mathrm{Ca}$ and $\mathrm{Mg}$ concentrations in 60 female patients who were diagnosed at Al-Shahida Layla Qassim Center, a specialized diabetic center. This study also aimed to compare 30 apparently healthy age-matched adults who were also enrolled in this study and designated as the control group. This case-control study was performed at Hawler Medical University, College of Pharmacy, Clinical Analysis Department in Kurdistan Governorate, Iraq. The samples were collected from August 2015 to January 2016. The patients with T2DM were diagnosed by a specialist physician after they were clinically examined and confirmed through laboratory tests at a diabetic center.

A fasting blood sample were collected from the patients with T2DM $(n=60$; mean age of $44.54 \pm 12.28$ years) and controls $(n=30)$ who were matched in terms of gender and age ( \pm 5 years; mean age of $39.56 \pm 8.98$ years). The control group was confirmed normal through biochemical and hematological examinations.

The procedures were performed in accordance with the established ethical standards. Verbal informed consents were obtained before the study was initiated. The study protocol was approved by the Ethics Com- 
mittee of the Medical Research at the College of Pharmacy of Hawler Medical University.

The participants were subjected to fasting overnight for 12-14 h. Fasting blood samples were then collected from the vein of the participants without using a tourniquet. The blood samples were left to stand for $30 \mathrm{~min}$ to achieve coagulation and then centrifuged for $15 \mathrm{~min}$ at 2,500-3,500 rpm. The sera of the patients were separated and divided into several parts, placed into several plastic plain tubes, and subjected to biochemical analysis.

Patients were excluded from the study when the following criteria were satisfied: patients with cardiovascular diseases, stroke or transient ischemic attacks, uncontrolled hypertension, liver disease, renal disease, severe dyslipidemia, pregnant women with diabetes, and individuals taking lipid-lowering agents. Patients were also excluded with evident inflammation by performing a CRP test as an indicator. Patients manifested inflammation when CRP was positive (CRP $>6 \mathrm{mg} / \mathrm{l})$. As such, they were also excluded from the study. However, fetuin-A is considered a negatively acute-phase reactant protein; therefore, its concentration in the serum is decreased during acute and chronic inflammation (14). Serum fetuin-A levels also significantly reduce under inflammatory conditions and weaken inflammatory responses (15). This protein also plays an anti-inflammatory role to counterregulate the effect of innate immune responses. FetuinA experimentally was suggested as an anti-inflammatory agent. This study was considered the first attempt to evaluate negative CRP and to determine the variation in serum fetuin-A levels because of T2DM and not of other factors.

Serum fetuin-A level was estimated by using enzyme-linked immunosorbent assay (ELISA) kits supplied by Monobind ${ }^{\circledR}$ (USA). Serum insulin levels were determined through DRG $^{\circledR}$ Insulin ELISA in accordance with the sandwich principle.

The total Ca content in the serum was measured using a ready-to-use kit in accordance with the Arsenazo III method. The corrected Ca content was calculated by using the following equation (16):

Corrected Ca content $=$ total $\mathrm{Ca}($ in $\mathrm{mg} / \mathrm{dl}) /(0.6$

$+0.05 \times$ total protein)

Ionized $\mathrm{Ca}$ levels in the serum were determined as follows (16):

Ionized Ca level $=0.9+(0.55 \times$ T.Ca in mmol/ 1)-(0.3×albumin)

Total Mg in the serum was measured in accor- dance with the calamite method by using a kit supplied by Cypress Co. Ionized $\mathrm{Mg}$ levels in the serum were calculated by using the following equation (17):

Ionized $\mathrm{Mg}$ in $\mathrm{mmol} / \mathrm{l}=[0.66 \times(\mathrm{T} . \mathrm{Mg}$ in $\mathrm{mmol} /$ 1)] +0.039

IR parameters (HOMA2IR, HOMA\%B, and $\mathrm{HOMA} \% \mathrm{~S}$ ) were determined by using homeostatic model assessment to estimate the stable state of $\beta$-cell function (HOMA2) calculated via fasting glucose and insulin.

The model was recalibrated to $100 \%$ in normal young adults when currently available assays were used to measure fasting blood glucose and insulin (United Kingdom prospective Diabetes Study group at Oxford University). Ideal normal-weight individuals aged $<35$ years should yield a HOMA2IR of $1 \mathrm{~mol} \mu \mathrm{U} / \mathrm{I}^{2}$ and a HOMA\%B cell function of $100 \%$.The serum levels of total protein, albumin, and glucose were determined by using colorimetric methods via readyto-use kits (Agappe ${ }^{\circledR}$, Switzerland).

\section{Statistical analysis}

Data were analyzed by using SPSS version 21 (2013; IBM, USA). Figures were constructed using Microsoft Excel 2010.

Results were examined using a KolmogorovSmirnov test. On the basis of analysis results, we divided the variables into two groups according to statistical distribution: normally distributed and nonparametric variables. The two groups were compared in terms of between patients and controls or between subdivided groups with the parameters measured through $t$ test. $r$ value was measured to estimate the correlation between parameters.

For normally distributed variables, results were expressed as mean \pm standard deviation (SD). Pooled $t$ test was conducted to compare data between patients and controls and among the subdivided groups in terms of the measured parameters. Pearson's correlation coefficients $(r)$ were calculated to determine the correlation between parameters.

For non-normally distributed nonparametric variables, results were expressed as median and mean \pm SD. Mann-Whitney $U$ test was performed to compare data between patient and control groups and among subdivided groups in the measured parameters. Spearman's correlation coefficients ( $\varrho$, rho) were used to estimate the correlation between parameters. $P<0.05$ was considered statistically different. 


\section{RESULTS}

The results of the descriptive variables of patients and control groups are summarized in Table 1. The weight, height, and BMI of patients did not significantly differ.

Table 1: Descriptive parameters in T2DM patients and control groups expressed as mean \pm SD (N.S.=not significant, $p$-value is not cited if $p>0.05$ ).

\begin{tabular}{lccc}
\hline \hline Parameter & Patients & Control & $p$-value \\
\hline Age (year) & $44.54 \pm 12.28$ & $39.56 \pm 8.98$ & N.S. \\
\hline Weight $(\mathrm{kg})$ & $72.64 \pm 14.58$ & $68.98 \pm 17.32$ & N.S. \\
\hline Height $(\mathrm{cm})$ & $1.68 \pm 0.19$ & $1.67 \pm 0.26$ & N.S. \\
\hline BMI $\left(\mathrm{kg} / \mathrm{m}^{2}\right)$ & $27.36 \pm 3.84$ & $26.74 \pm 3.04$ & N.S. \\
\hline \hline
\end{tabular}

Serum fetuin-A level, represented as a median, was significantly different $(p<0.001$; Figure 1$)$ between patients $(1,433 \mu \mathrm{g} / \mathrm{ml})$ and controls $(911 \mu \mathrm{g} / \mathrm{ml})$. Data were expressed as median.

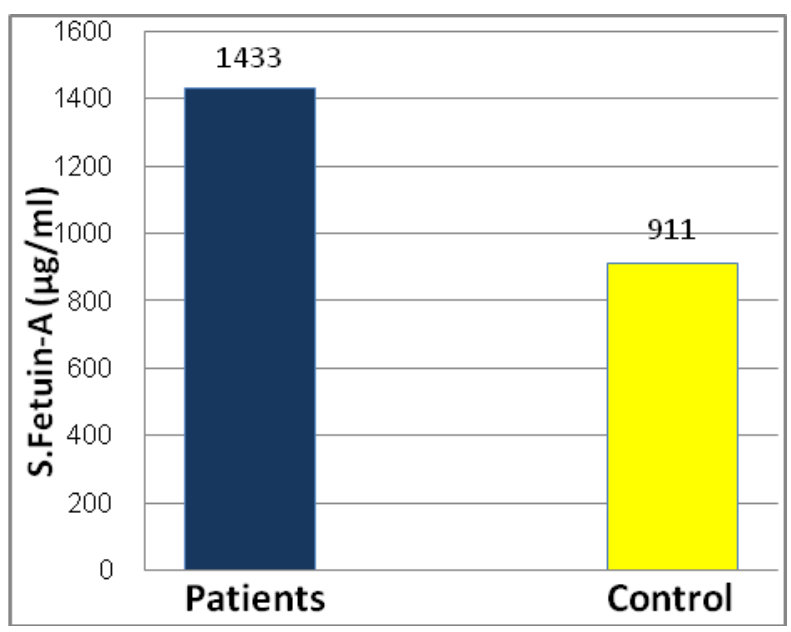
controls

Figure 1: Serum fetuin-A level in patients and

The IR parameters in T2DM patients and controls were expressed as mean $\pm \mathrm{SD}$ and medians in brackets (Table 2). Fasting insulin levels and HOMA2IR were significantly greater $(p<0.05)$ in the patients with T2DM than in the controls. By contrast, HOMA2\%S was significantly lower in the patients with T2DM than in the controls $(p<0.05)$.

The total $\mathrm{Mg}$ (T.Mg; $0.79 \pm 0.23$ vs. $0.89 \pm 0.17$ $\mathrm{mmol} / \mathrm{l}$ ), ionized $\mathrm{Mg}$ (I.Mg; $0.56 \pm 0.15$ vs. $0.62 \pm 0.11$ $\mathrm{mmol} / \mathrm{l})$, and I.Ca/Mg $(1.94 \pm 0.46$ vs. $2.23 \pm 0.66)$ in the T2DM patients were significantly lower than those in the normal patients $(p<0.05$; Table 3$)$.

Table 2: IR parameters in patients with T2DM and control groups expressed as mean \pm SD (median are in brackets).

\begin{tabular}{llll}
\hline \hline Parameter & Patients & Control & $p$ value \\
\hline Insulin $(\mathrm{mIU} / \mathrm{l})$ & $(4.24)$ & $(7.58)$ & $0.004^{*}$ \\
\hline FBS $(\mathrm{mmol} / \mathrm{l})$ & $9.39 \pm 2.26$ & $5.31 \pm 0.81$ & $0.002^{*}$ \\
\hline $\mathrm{I} / \mathrm{G}(\mathrm{IU} / \mathrm{mol})$ & $(0.45)$ & $(1.43)$ & $0.002^{*}$ \\
\hline HOMA2\%B & $(62.63)$ & $(91.44)$ & $0.011^{*}$ \\
\hline HOMA2\%S & $(57.28)$ & $(94.19)$ & $0.012^{*}$ \\
\hline $\begin{array}{l}\text { HOMA2IR } \\
\left(\mathrm{mol} \cdot \mu \mathrm{U} / \mathrm{I}^{2}\right)\end{array}$ & $(4.10)$ & $(2.01)$ & $0.007^{*}$ \\
\hline \hline \multicolumn{4}{c}{$p<0.05$, significant difference }
\end{tabular}

Table 3: Serum cations in the patients with T2DM and the control group

\begin{tabular}{llll}
\hline Parameter & Control & Patients & $p$-value \\
\hline T.Mg & $0.89 \pm 0.17$ & $0.79 \pm 0.23$ & $0.004^{*}$ \\
\hline I.Mg & $0.62 \pm 0.11$ & $0.56 \pm 0.15$ & $0.004^{*}$ \\
\hline T.Ca & $2.16 \pm 0.34$ & $2.15 \pm 0.30$ & 0.911 \\
\hline I.Ca & $1.18 \pm 0.19$ & $1.17 \pm 0.17$ & 0.948 \\
\hline T.Ca/Mg & $2.53 \pm 0.63$ & $2.94 \pm 0.95$ & 0.054 \\
\hline I.Ca/Mg & $2.23 \pm 0.66$ & $1.94 \pm 0.46$ & $0.043^{*}$ \\
\hline \hline
\end{tabular}

${ }^{*} p<0.05$, significant difference

Table 4: Serum proteins in patients with T2DM and controls

\begin{tabular}{lccc}
\hline \hline Parameter & Control & Patients & $p$-value \\
\hline $\begin{array}{l}\text { Albumin } \\
(\mathrm{g} / \mathrm{dl})\end{array}$ & $4.29 \pm 0.35$ & $4.01 \pm 0.44$ & 0.067 \\
\hline $\begin{array}{l}\mathrm{T} . \text { Protein } \\
(\mathrm{g} / \mathrm{dl})\end{array}$ & $7.18 \pm 0.62$ & $7.39 \pm 1.08$ & 0.088 \\
\hline $\mathrm{S} . \mathrm{Ig}(\mathrm{g} / \mathrm{dl})$ & $2.89 \pm 0.74$ & $3.38 \pm 0.45$ & $0.018^{*}$ \\
\hline $\mathrm{Alb} / \mathrm{Glb}$ & $1.48 \pm 0.41$ & $1.17 \pm 0.64$ & $0.032^{*}$ \\
\hline \hline
\end{tabular}

${ }^{*} p<0.05$, significant difference

Serum albumin content and $\mathrm{Alb} / \mathrm{Glb}$ ratio in the patients with T2DM were significantly lower than those of the control group. By contrast, serum globulin contents in patients were significantly higher in the patient group than in the control group (Table 4). 
The serum total protein levels in the patient group were significantly different from those in the control group $(p=0.088)$.
Fetuin-A was correlated with the measured parameters (Table 5). Fetuin-A was also significantly correlated with IR and $\beta$-cell functions in the patient group.

Table 5: Correlation between fetuin-A and IR parameters

\begin{tabular}{|c|c|c|c|c|c|c|c|c|}
\hline & & & Insulin & FBS & $\mathrm{I} / \mathrm{G}$ & HOMА $2 \% B$ & HOMA $2 \% S$ & HOMA2IR \\
\hline \multirow{4}{*}{ Fetuin-A } & \multirow{2}{*}{ Patients } & $r$ & 0.15 & 0.17 & 0.23 & 0.23 & 0.11 & 0.28 \\
\hline & & $p$ & 0.32 & 0.24 & 0.06 & $0.04^{*}$ & 0.09 & $0.02^{*}$ \\
\hline & \multirow{2}{*}{ Control } & $r$ & 0.14 & 0.12 & 0.12 & 0.11 & 0.19 & 0.17 \\
\hline & & $p$ & 0.13 & 0.21 & 0.18 & 0.13 & 0.22 & 0.09 \\
\hline
\end{tabular}

${ }^{*} p<0.05$, significant difference

Table 6 shows the correlation between fetuin-A and cations. Serum fetuin-A was correlated with T.Ca and serum albumin in the patients with diabetes. The examined cations and ratios were correlated with serum fetuin-A in the patients with T2DM and the control group.

Table 6: Correlation of fetuin-A with divalent cations and other parameters

\begin{tabular}{|c|c|c|c|c|c|c|c|c|c|c|c|c|}
\hline & & & T.Mg & I.Mg & T.Ca & I.Ca & T.Ca/Mg & I.Ca/Mg & Alb & T.Pr & S.Glb & Alb/Glb \\
\hline \multirow{4}{*}{$\begin{array}{c}\text { Fetuin- } \\
\text { A }\end{array}$} & \multirow{2}{*}{ Patients } & $r$ & 0.09 & 0.09 & 0.32 & 0.28 & 0.17 & 0.18 & -0.33 & -0.17 & -0.12 & 0.07 \\
\hline & & $p$ & 0.37 & 0.37 & $0.03 *$ & 0.40 & 0.09 & 0.12 & $0.02 *$ & 0.09 & 0.10 & 0.21 \\
\hline & \multirow{2}{*}{ Control } & $r$ & 0.11 & 0.11 & 0.19 & 0.18 & 0.21 & 0.20 & -0.18 & -0.11 & 0.17 & 0.12 \\
\hline & & $p$ & 0.19 & 0.19 & 0.27 & 0.09 & 0.27 & 0.16 & 010 & 0.09 & 0.15 & 0.24 \\
\hline
\end{tabular}

${ }^{*} p<0.05$, significant difference

\section{DISCUSSION}

T2DM is a very common disease in Iraq. The number of diabetes cases increases at an alarming rate every year. As such, cost-effective and efficient measures should be implemented.

This study is the first to report serum fetuin-A, IR, and impaired $\beta$-cell function in patients with T2DM and negative CRP.

T2DM is a heterogeneous disorder caused by a complex interplay of genetic susceptibility and lifestyle choices; as a result, IR occurs and $\beta$-cell functioning becomes damaged. The T2DM pathophysiology involves many processes, including damaged insulin produced by $\beta$-pancreatic cells and decreased insulin sensitivity (3).

The descriptive parameters of the participants are presented in Table 1. Figure 1 illustrates that fetuin-A is a nondependent risk factor of T2DM incidence and is associated with IR. The findings of the present study and those described in a previous study (6) supported that fetuin-A or fetuin-A-induced
IR may disrupt insulin secretion and disturb glucose homeostasis.

In our study, serum fetuin-A level indicated the occurrence of T2DM. Our results revealed that the fetuin-A concentration in T2DM patients was significantly higher than that of the control group (Figure 1). This finding suggested that the fetuin-A concentration was independently related to T2DM development. Consistent with a previous study (6), our study revealed that fetuin-A induced IR and possibly exacerbated insulin release; as a consequence, glucose homeostasis is disrupted.

Fetuin-A was related to the increased risk of diabetes, especially in people with high blood glucose level (6). High fetuin-A level was also independently but positively related to IR. In both genders, fetuin-A is positively correlated with IR (18). Therefore, fetuinA may play an important role in the pathophysiology of T2DM (19). Our results are consistent with those described in previous studies (20, 21). Moreover, serum fetuin-A is related to prediabetes, diabetes type 2 , and IR in Chinese population aged $\geq 40$ years (22). 
The IR parameters of the patients with T2DM and the control subjects were expressed as mean \pm SD and medians in brackets (Table 2). Fasting insulin levels and HOMA2IR were significantly greater $(p<$ 0.05 ) in the patients with T2DM than in the control subjects. By contrast, HOMA2\%S was significantly lower $(p<0.05)$ in the patients with T2DM than in the control subjects. $\beta$-cell functioning (HOMA2\%B) was also lower in the patients with T2DM than in the control subjects.

Our study demonstrated that serum fetuin-A was related to IR, and HOMA2IR index and fasting insulin serum levels were increased; this result is consistent with previous results $(4,22-24)$. Therefore, fetuin-A may be used as a new factor implicated in T2DM pathology and physiology; IR also plays an important role in the T2DM mechanism (25). IR is also an important link between fetuin-A and T2DM. Fetuin-A induces IR by inhibiting insulin receptor autophosphorylation (26). IR is also one of the pathophysiological T2DM mechanisms, which may be involved in the prevalence of T2DM and associated vascular complications. Fetuin-A plays a special role in glucose homeostasis, as indicated by the fetuin-Aencoding gene present on chromosome 3q27; this region of the chromosome was previously mapped as a T2DM-susceptible locus (27). Genetic analyses have exhibited that a change in single nucleotide in the fetuin-A gene is involved in T2DM (28). Therefore, fetuin-A concentration should be estimated to detect people who are at a high risk of T2DM development.

Fasting insulin level decreased significantly in the patient with T2DM ( $p=0.004$; Table 2). HOMA2IR was increased in the patients with T2DM ( $p=0.007$; Table 2). Our result is consistent with previous findings (21). By contrast, insulin sensitivity (HOMA2\%S) was decreased significantly in the patients with T2DM $(p=0.012)$, and $\beta$-cell function (HOMA2\%B) was increased significantly in the control group ( $p=0.011$; Table 2 ). Therefore, serum fetuin-A levels indicated the occurrence of IR in T2DM. Indeed, IR is the underlying mechanism of T2DM (25).

Fasting hyperglycemia was induced by a damage in the function of $\beta$-pancreatic cells to release insulin, which is the most predominant factor contributing to the T2DM pathogenesis. Therefore, fetuin-A or fetuin-A-induced IR may deteriorate insulin secretion and disrupt glucose homeostasis (6).

The mean age of the patients was $44.54 \pm 12.28$ years (Table 1), and this information was compatible with those in other studies; high T2DM incidence rates were observed with increasing age (29). The risk factors of diabetes are age, gender, BMI, waist measurement, and other contributing factors. FetuinA is also correlated with pre-diabetes, T2DM, and IR in a Chinese population aged $\geq 40$ years old (22). Fetuin-A is also related to T2DM in an American population aged $>70$ years (30) and in a German population aged 35-65 years (6). Patients with T2DM yielded high fetuin-A levels with age $\geq 71$ years (31). T2DM has been considered a global epidemic that affects not only elder people but also young individuals, especially those who are obese.

In our study, the BMI of the patients was 27.36 $\pm 3.84 \mathrm{~kg} / \mathrm{m}^{2}$ (Table 1). As such, these patients are classified as obese (BMI > 25). Obesity presented by the increased BMI in patients with T2DM may increase the production of fetuin- $\mathrm{A}$, which may induce IR. However, the relationship of fetuin-A with BMI remains unclear (32). Furthermore, IR plays a major role in the occurrence of T2DM and exhibits a strong association with several metabolic risk factors, such as obesity.

The metabolism of several essential elements is altered during $\mathrm{DM}$, and these elements may be involved in the etiology of T2DM. For example, insulin release is dependent on the availability of Ca. Consistent with a previous study (33), our study revealed that the total Ca serum level was lower in the patients with T2DM than in the control group (Table 3). This result indicated that the Ca activity is possibly implicated in T2DM occurrence and progression. Furthermore, Ca serum level is remarkably associated with T2DM. A potential link is also found between Ca serum level deficiency and T2DM.

Many events, such as $\beta$-pancreatic cell impairment, inflammation, and insulin sensitivity, contribute to the potential mechanisma of the effects of Ca on T2DM and the occurrence of T2DM (34). Ca release is dependent on Ca availability (35). Therefore, variations in Ca flux can elicit side effects on $\beta$-cell secretion. Randomized trials on the effect of Ca intake have revealed improvement in IR (36). For example, a decrease in Ca uptake is negatively related to the occurrence of T2DM (12).

Ca intake is negatively related to the occurrence of T2DM when vitamin D intake is completely adjusted (16). Serum Ca is also negatively related to T2DM in black women in a cohort prospective study of approximately 59.000 individuals at a baseline of women aged 21-69 years (12). 
Magnesium activates many enzyme functions involved in carbohydrate metabolism. $\mathrm{Mg}$ is also associated with insulin function because $\mathrm{Mg}$ is essential for insulin activity. A decrease in intracellular Mg level enhances IR (37). In addition, $\mathrm{Mg}$ is necessary to induce tyrosine-kinase activity and stimulate insulin to reduce blood glucose level Therefore, a daily $\mathrm{Mg}$ intake increases insulin sensitivity by $10 \%$ and decreases blood glucose level by $37 \%$ (38). In our study, the total Mg concentration was significantly decreased in the patients with T2DM (Table 3). This result is also consistent with that described in a previous study, which revealed a connection between T2DM and Mg deficiency (23). Low serum $\mathrm{Mg}$ is a strong independent predisposing factor of IR and T2DM development (39). Therefore, reduced serum $\mathrm{Mg}$ level in T2DM may be associated with an increased urinary loss of $\mathrm{Mg}$ (9). These results are also consistent with those described in other studies. Hence, the deficiency and efficiency of essential trace metals may be implicated in T2DM development. Magnesium is reabsorbed from renal tubules. $\mathrm{Mg}$ reabsorption in these segments is enhanced by insulin. IR in DM can enhance $\mathrm{Mg}$ excretion through the kidney. Thus, reduced serum $\mathrm{Mg}$ level in T2DM may promote the urinary loss of $\mathrm{Mg}$ (9). These results indicated that the reduction of the serum levels of some essential trace metals may be associated with the occurrence of T2DM.

Increased loss through the kidney, reduced $\mathrm{Mg}$ intake from nutrients, and decreased absorption are several factors that contribute to the reduction of $\mathrm{Mg}$ serum levels in diabetes (9). The osmotic action of glucosuria prevents the net tubular reabsorption of $\mathrm{Mg}$ (40). The connection between the loss of $\mathrm{Mg}$ and the occurrence of DM is supported by therapeutic findings on T2DM, which likely increase $\mathrm{Mg}$ levels. For example, metformin increases $\mathrm{Mg}$ levels in hepatic cells. Our study also suggested that patients with diabetes should consume Mg-rich food, such as legumes and whole grains. They should also include fruits, vegetables, and other types of food rich in nutrients and antioxidants.

The increase in total protein in patients with T2DM did not significantly differ from that in the control groups $(p=0.088)$. The serum albumin levels in the patients were decreased ( $p=0.067)$, but their serum immunoglobulin levels were significantly increased (Table 4). Total protein may increase because of dehydration or the loss of water from the body because of diabetes and osmotic effect of glucose. This condition also decreases albumin concentration and increases globulin content in dysfunctional kidneys, which are observed in patients with diabetes. In another study (31), serum levels of total protein, albumin, and globulin in patients with T2DM are higher than those in the control group, but their difference is not significant $(p>0.05)$.

Fetuin-A is significantly correlated with IR and $\beta$-cell functioning in the patient group. Our study demonstrated that fetuin-A was positively correlated with HOMA-IR and $\beta$-cell functioning in the patients with T2DM (Table 5). These results confirmed the importance of fetuin-A in insulin functioning and DM (4). Our results are also consistent with those described in a previous study (21), which revealed that fetuin-A is positively and significantly correlated with IR. Other parameters were also significantly and positively correlated with serum fetuin- $A$; therefore, increased fetuin-A level is associated with IR. However, the increased serum fetuin-A level is not significantly correlated with the loss of glucose regulation (22).

The early detection of serum fetuin-A levels provides an opportunity for the timely treatment and prevention of vascular complications associated with diabetes. Serum $\mathrm{Mg}$ level in patients with T2DM helps enhance our understanding of serum $\mathrm{Mg}$ reduction among patients with T2DM. Therefore, preventive measures can be implemented to reduce the risk of this disease.

\section{CONCLUSION}

This study demonstrated the effect of fetuin-A on IR. Fetuin-A was significantly related to IR in Erbil patients with diabetes. Fetuin-A could also be considered an IR modulator in humans. High plasma fetuin-A level is a new independent marker that predicts the incidence of T2DM and IR in aged Iraqi patients. IR is also necessary to determine the relationship between fetuin-A and T2DM. The significant increase in human serum fetuin-A indicated that fetuin-A could be a target for T2DM treatment by blocking the binding of fetuin-A to the insulin receptor. This mechanism is considered a new therapeutic strategy to prevent or treat IR-related clinical conditions. Serum $\mathrm{Ca}$ and $\mathrm{Mg}$ levels were also significantly decreased in T2DM. Serum insulin and other IR-related parameters, including HOMA2IR score and glucose level, were significantly increased 
in T2DM. Nevertheless, further studies are necessary to elucidate the exact relationship between fetuin-A and IR in T2DM. Further investigations should also be performed to develop strategies that use fetuin-A as a predictor of complicated outcomes in patients with diabetes.

\section{Abbreviations}

BM - Body mass index; Ca - Calcium; CVD Cardiovascular disease; CRP - C-reactive protein; DM - Diabetes mellitus; ELISA - Enzyme-linked immunosorbent assay (ELISA); IR - Insulin resistance; IFG Impaired fasting glucose; IGT - Impaired glucose tolerance; Mg - magnesium, T2DM - Type 2 diabetes mellitus; US - United States.

\section{References}

1. Wild S, Rolic C, Green A. Global prevalence of diabetes: Estimates for the year 2000 and projection for 2030. Diabetes Care 2004;37:104753

http://dx.doi.org/10.2337/diacare.27.5.1047

2. Rasic MZ, Perunicic PG, Pljexa S et al. Magnesium deficiency in type 2 diabetes. Hippokratia 2004;8(4):179-81.

3. Stumvoll M, Goldstein BJ, van Haeften TW. Type 2 diabetes: principles of pathogenesis and therapy. Lancet 2005; 365: 1333-46.

http://dx.doi.org/10.1016/S0140-6736(05)61032-X

4. Stefan N, Hennige AM, Staiger $\mathrm{H}$ et al. $\alpha 2-$ Heremans-Schmid glycoprotein/fetuin-A is associated with insulin resistance and fat accumulation in the liver in humans. Diabetes Care 2006; 29: 853-57.

http://dx.doi.org/10.2337/diacare.29.04.06.dc05-1938

5. Cintrón VJ, Ko MS, Chi KD et al. Genetic mapping and functional studies of a natural inhibitor of the insulin receptor tyrosine kinase: the mouse ortholog of human alpha2-HS glycoprotein. Int J Exp Diabetes Res 2001; 1(4): 249-63.

http://dx.doi.org/10.1155/EDR.2000.249

6. Stefan N, Fritsche A, Weikert C et al. Plasma Fetuin-A Levels and the Risk of Type 2 Diabetes.Diabetes 2008; 57(10): 2762-7. http://dx.doi.org/10.2337/db08-0538
7. Ketteler $\mathrm{M}$, Bongartz $\mathrm{P}$, Westenfeld $\mathrm{R}$ et al. Association of low fetuin-A (AHSG) concentrations in serum with cardiovascular mortality in patients on dialysis: a crosssectional study. Lancet 2003; 361: 827-33. http://dx.doi.org/10.1016/S0140-6736(03)12710-9

8. Zeitz U, Weber K, Soegiarto DW et al. Impaired insulin secretory capacity in mice lacking a functional vitamin Dreceptor. FASEB J 2003; 17:509-11

9. Pham PCT, Pham PMT, Pham SV, Miller JM and Pham PTT. Hypomagnesemia in patients with Type 2 Diabetes.Clin J Am SocNephrol2007; 2:366-73. http://dx.doi.org/10.2215/CJN.02960906

10. Kobrin SM, and Goldfarb S. Magnesium Deficiency. SeminNephrol 1990; 10: 525-35.

11. Hua H, Gonzales J, Rude RK. Magnesium transport induced ex vivo by a pharmacological dose of insulin is impaired in non-insulindependent diabetes mellitus. Magnes-Res 1995; 8 (4): 359-66.

12. van Dam RM, Hu FB, Rosenberg L et al. Dietary calcium and magnesium, major food sources, and risk of type 2 diabetes in U.S. black women. Diabetes Care 2006; 29:2238-43.

http://dx.doi.org/10.2337/dc06-1014

13. Paolisso G, Sgambato S, Pizza G et al. Improved insulin response and action by chronic 
magnesium administration in aged NIDDM subjects. Diabetes Care 1989;12:262-9.

http://dx.doi.org/10.2337/diacare.12.4.265

14.14-Wang H, Sama AE. Anti-inflammatory role of fetuin-A in injury and infection. Curr Mol Med 2012; 12:625-633.

http://dx.doi.org/10.2174/156652412800620039

15. Bonora E, Targher G, Alberiche $\mathrm{M}$, et al. Homeostasis model assessment closely mirrors the glucose clamp technique in the assessment of insulin sensitivity: studies in subjects with various degrees of glucose tolerance and insulin sensitivity. Diabetes Care 2000; 23: 57-63. http://dx.doi.org/10.2337/diacare.23.1.57

16. Dickerson RN, Alexander KH, Minard G Croce MA, Brown RO. Accuracy of methods to estimate ionized and"corrected" serum calcium concentrations in critically ill multiple trauma patients receiving specialized nutrition support. JPEN J Parenter Enteral Nutr 2004; 28(3):13341.2004; 28:133-141.

17. Koch SM, Warters D, Mehlhorn U. Thesimulaneous measurement of ionized and total calcium and ionized and total magnesium in intensive care unit patients. J Crit Care 2002; 17(3):203-5.

http://dx.doi.org/10.1053/jcrc.2002.35813

18. Laughlin GA, Barrett-Connor E, Cummins KM, et al. Sex-Specific Association of Fetuin-A With Type 2 Diabetes in Older Community-Dwelling Adults.The Rancho Bernardo Study. Diabetes Care2013; 36(7): 1994-2000. http://dx.doi.org/10.2337/dc12-1870

19. Dasgupta S, BhattacharyaS, BiswasA. NF- $\kappa B$ mediates lipid-induced fetuin-A expression in hepatocytes that impairs adipocyte function effecting insulin resistance. Biochem J 2010; 429:451-62.

http://dx.doi.org/10.1042/BJ20100330

20. SunQ, CornelisMC, Manson JE, HuFB. Plasma levels of fetuin-A and hepatic enzymes and risk of type 2 diabetes in women in the U.S. Diabetes 2013;62(1):49-55.
21. Ahmed LI, Mousa SG, Mohamed NA et al. Fetuin-A and type II diabetes mellitus. Egypt J Intern Med 2014;26:157-61. http://dx.doi.org/10.4103/1110-7782.148140

22. Song $\mathrm{A}, \mathrm{Xu} \mathrm{M}, \mathrm{Bi} \mathrm{Y}$ et al. Serum fetuin-A associates with type 2 diabetes and insulin resistance in Chinese adults. PLoS ONE2011; 6(4): e19228. doi:10.1371/journal.pone.0019228. http://dx.doi.org/10.1371/journal.pone.0019228

23. Katsuhito Mori, Masanori Emoto, Hisayo Yokoyama et al. Association of serum fetuin-A with insulin resistance in type 2 diabetic and nondiabetic subjects. Diabetes Care 2006; 29(2): 468.

http://dx.doi.org/10.2337/diacare.29.02.06.dc05-1484

24. Ishibashi A, Ikeda $Y$, Ohguro $T$ et al. Serum fetuin-A is an independent marker of insulin resistance in Japanese men. J Atheroscler Thromb 2010; 17(9):925-33 http://dx.doi.org/10.5551/jat.3830

25. Lorenzo C, Wagenknecht LE, D'Agostino RB Jr et al. Insulin resistance, $\beta$-cell dysfunction, and conversion to type 2 diabetes in a multiethnic population: The Insulin Resistance Atherosclerosis Study. Diabetes Care 2010; 33(1): 67-72.

http://dx.doi.org/10.2337/dc09-1115

26. Mathews ST, Chellam N, Srinivas PR et al. Alpha2-HSG, a specific inhibitor of insulin receptor autophosphorylation, interacts with the insulin receptor. Mol Cell Endocrinol 2000; 164(1-2):87-98. http://dx.doi.org/10.1016/S0303-7207(00)00237-9

27. Vionnet N, Hani EH, Dupont $S$ et al. Genomewide search for type 2 diabetessusceptibility genes in French whites: evidence for a novel susceptibility locus for early-onset diabetes on chromosome 3q27-qter and independent replication of a type 2-diabetes locus on chromosome 1q21-q24. Am J Hum Genet 2000; 67: (6):1470-80. http://dx.doi.org/10.1086/316887

28. Siddiq A, Lepretre F, Hercberg S at al. A synonymous coding polymorphism in the $\alpha 2$ - 
Heremans-Schmid glycoprotein gene is associated with type 2 diabetes in French Caucasians. Diabetes 2005; 54(8): 2477-81. http://dx.doi.org/10.2337/diabetes.54.8.2477

29. Schulze MB, Schulz M, Heidemann $C$ et al. Carbohydrate intake and incidence of type 2 diabetes in the European Prospective Investigation into Cancer and Nutrition (EPIC)Potsdam Study. Br J Nutr 2008; 99(5): 1107-16. http://dx.doi.org/10.1017/S0007114507853360

30. Ix JH, Wassel CL, Kanaya AM et al. Health ABC Study. Fetuin-A and Incident Diabetes Mellitus in Older Persons: The Health Aging and Body Composition (Health ABC) Study. JAMA 2008; 300(2):182-8.

http://dx.doi.org/10.1001/jama.300.2.182

31. Jassem WE, and FarahanAR. The Effect of Age and Gender on Fetuin-A and Some Biochemical parameters in Blood Sera of Iraqi patients with T2DM: A comparative study. Baghdad Sci J 2015; 12(1):197-203.

32. Dabrowskaa AM, Taracha JS, Wojtysiak-Dumab B, Dumac D. Fetuin-A (AHSG) and its usefulness in clinical practice. Review of the literature. Biomed Pap Med FacUnivPalacky Olomouc Czech Repub 2015; 159(3):352-35.

33. KanchanaN, Saikumar P. Serum calcium levels In Type 2 Diabetes Mellitus. IOSR-JDMS 2014; 13(8): 01-03.

34. Hu FB, Meigs JB, Li TY et al. Inflammatory markers and risk of developing type 2 diabetes in women. Diabetes 2004;53(3):693-700.

http://dx.doi.org/10.2337/diabetes.53.3.693
35. Milner RD, Hales CN. The role of calcium and magnesium in insulin secretion from rabbit pancreas studied in vitro. Diabetologia 1967; 3(1):47-9.

http://dx.doi.org/10.1007/BF01269910

36. Pittas AG, Harris SS, Stark PC, Dawson-Hughes B. The effects of calcium and vitamin D supplementation on blood glucose and markers of inflammation in nondiabetic adults. Diabetes Care 2007;30:980-6.

http://dx.doi.org/10.2337/dc06-1994

37. Nadler JL, Buchanan T, Natarajan $\mathrm{R}$ et al. Magnesium deficiency produces insulin resistance and increased thromboxane synthesis. Hypertension 1993; 21(6 Pt 2): 1024-9. http://dx.doi.org/10.1161/01.HYP.21.6.1024

38. Guerrero-Romero F, Tamez-Perez HE, Gonzalez-Gonzalez G et al. Oral magnesium supplementationimproves insulin sensitivity in non-diabetic subjectswith insulin resistance. A double-blind placebo controlled randomized trial. Diabetes Metab 2004;30 (3): 253-8. http://dx.doi.org/10.1016/S1262-3636(07)70116-7

39. Walti MK, Zimmermann MB, Spinas GA, Hurrell RF. Low plasma magnesium in type 2 diabetes. Swiss Med Wkly 2003; 133(19-20): 28992.

40. Kareem I, Jaweed SA, Bardapurkar JS, Patil VP. Study of magnesium, Glycosylated hemoglobin and lipid profile in diabetic retinopathy. Indian J Clin Biochem 2004; 19(2):124-7. http://dx.doi.org/10.1007/BF02894270 


\title{
Povezanost insulinske rezistencije, poremećaja funkcije $\beta$ ćelija i koncentracija kalcijuma, magnezijuma i fetuina-A kod žena sa dijebetesom melitusom tipa 2
}

\author{
Shatha Rouf Moustafa \\ Farmaceutski fakultet, Medicinski fakultet Hawler, Erbil, Irak
}

SAŽETAK

Insulinska rezistencija i poremećaj funkcije $B$ ćelija imaju važnu ulogu u patogenezi dijabetesa melitusa tipa 2 (T2DM). Insulinsku signalizaciju inhibiše fetuin-A, fiziološki prisutan protein u plazmi. Fetuin-A je takođe potencijalni marker za procenu rizika od T2DM. Cilj ove studije slučaja-kontrole bio je da ispita da li je nivo fetuina-A u serumu povezan sa insulinskom rezistencijom, poremećajem funkcije $\mathbb{B}$ ćelija i nivoima ukupnog i jonizujućeg Ca i Mg u serumu kod bolesnica sa dijebetesom melitusom tipa 2 koje žive u Erbilu.

Ispitano je ukupno 60 bolesnica sa T2DM, dok je kontrolnu grupu činilo 30 zdravih osoba. Vrednosti fetuina-A i koncentracije insulina mereni su pomoću ELISA metode. Ostali biohemijski parametri su određeni spektrofotometrijskom metodom. Insulinska rezistencija, insulinska senzitivnost, kao i funkcija $ß$ ćelija su analizirane pomoću homeostatskog modela procene (HOMA2).

Nivoi insulina u serumu nakon gladovanja, fetuina-A i insulinske rezistencije (HOMA2IR) bili su značajno povećani. Insulinska senzitivnost (HOMA2\%S) kod bolesnica sa dijabetesom bila je značajno niža nego kod ispitanika kontrolne grupe. Nivoi ukupnog i jonizujućeg Ca i $\mathrm{Mg}$ u serumu, kao i odnos $\mathrm{Ca} / \mathrm{Mg}$, bili su sniženi kod bolesnica.

Proističe da je fetuin-A povezan sa patogenezom T2DM i da je usko povezan sa insulinskom rezistencijom i kontrolom šećera $u$ krvi kod osoba sa dijabetesom melitusom tipa 2 . Neophodno je sprovesti nove opsežne studije da bi se dokazalo da je fetuin-A indikator insulinske rezistencije kod bolesnika sa dijabetesom melitusom.

Ključne reči: Ca, fetuin-A, dijabetes melitus tip 2, insulinska rezistencija, $\mathrm{Mg}$ 